\title{
"The effect of internal control environment on the value relevance of earnings"
}

\begin{tabular}{|c|c|}
\hline AUTHORS & Hyun-Ah Lee (D) http://orcid.org/0000-0001-5435-3192 \\
\hline ARTICLE INFO & $\begin{array}{l}\text { Hyun-Ah Lee (2019). The effect of internal control environment on the value } \\
\text { relevance of earnings. Investment Management and Financial Innovations, 16(2), } \\
\text { 182-194. doi:10.21511/imfi.16(2).2019.16 }\end{array}$ \\
\hline DOI & http://dx.doi.org/10.21511/imfi.16(2).2019.16 \\
\hline RELEASED ON & Thursday, 06 June 2019 \\
\hline RECEIVED ON & Tuesday, 26 March 2019 \\
\hline ACCEPTED ON & Tuesday, 28 May 2019 \\
\hline LICENSE & $\begin{array}{l}(c)) E Y \\
\text { This work is licensed under a Creative Commons Attribution } 4.0 \text { International } \\
\text { License }\end{array}$ \\
\hline JOURNAL & "Investment Management and Financial Innovations" \\
\hline ISSN PRINT & $1810-4967$ \\
\hline ISSN ONLINE & $1812-9358$ \\
\hline PUBLISHER & LLC "Consulting Publishing Company "Business Perspectives" \\
\hline FOUNDER & LLC "Consulting Publishing Company "Business Perspectives" \\
\hline $0^{\circ}$ & $\begin{array}{l}\text { 三ニ } \\
\text { 三汪 }\end{array}$ \\
\hline NUMBER OF REFERENCES & NUMBER OF FIGURES \\
\hline 32 & 7 \\
\hline
\end{tabular}

(c) The author(s) 2021. This publication is an open access article. 


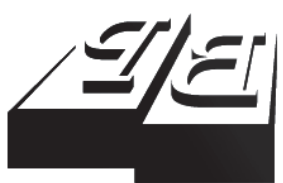

BUSINESS PERSPECTIVES

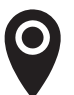

LLC "CPC "Business Perspectives" Hryhorii Skovoroda lane, 10, Sumy, 40022, Ukraine

www.businessperspectives.org

Received on: $26^{\text {th }}$ of March, 2019 Accepted on: $28^{\text {th }}$ of May, 2019

(C) Hyun-Ah Lee, 2019

Hyun-Ah Lee, Assistant Professor, School of Business, Gachon

University, Korea.

\section{THE EFFECT OF INTERNAL CONTROL ENVIRONMENT ON THE VALUE RELEVANCE OF EARNINGS}

\begin{abstract}
This study examines whether a suitable control environment increases the value relevance of earnings by providing greater assurance on the reliability of financial reporting. Specifically, the level of suitable control environment is assessed by considering the quantity and quality of IC personnel, which are closely related to the personnel integrity/ethical values, competence, and authority/responsibility. Using a sample of 1,834 firm-year observations of Korean listed companies covering 2005-2010, the author finds that earnings are more value relevant when the increase in the average work experience of IC personnel is greater. However, no evidence is found that the value relevance of earnings is positively associated with the increase in the proportion of IC personnel. The findings suggest that a suitable control environment, established by deployment of qualified IC personnel with more work experience, improves the IC effectiveness and, thus, provides greater assurance on the reliability of financial reporting to market investors.
\end{abstract}

\section{Keywords Sarbanes-Oxley Act, internal control system, internal} control personnel, financial reporting, work experience

\section{JEL Classification M41, O15, G32}

\section{INTRODUCTION}

This study investigates the effect of internal control (IC) environment on the value relevance of earnings. The control environment is the foundation of the components in the IC framework for carrying out effective control system (COSO, 2013). A suitable control environment, represented by the personnel integrity/ethical values, competence, and authority/responsibility, is expected to improve the effectiveness of IC and thus provide reliable financial reporting.

According to the guidance to auditors on audit considerations, issued by the Public Company Accounting Oversight Board (PCAOB), the loss of employees integral to the operation of ICs may increase the risk of deficiencies in IC over financial reporting owing to the lack of segregation of duties or effective controls (PCAOB, 2008). In addition, a publication from Deloitte encourages the use of knowledgeable personnel with appropriate skills in control activities to make sure that the ICs are operating effectively (Deloitte, 2013). Therefore, I assume that the management who value the personnel integrity/ethical values, competence, and authority/responsibility would establish a suitable IC environment by allocating more employees and qualified ones with longer work experience. Then, the reported earnings of the firms with a suitable control environment would be perceived as more informative and reliable in the valuation process, thereby leading to an increase in the value relevance of earnings. 
Based on the assumption above, I empirically test whether the value relevance of earnings is affected by a suitable control environment, using a sample of 1,834 firm-year observations of Korean listed companies covering 2005-2010. The level of suitable control environment is measured by the ratio of the number of IC personnel to the total number of employees in the firm and the average work experience of IC personnel (Choi et al., 2013; Shin et al., 2016). My findings can be summarized as follows. First, I find that earnings are more value relevant when the increase in work experience of the firm's IC personnel is greater. This suggests that allocation of more experienced personnel to the IC function would send a positive signal to the market that the firm's reported earnings are more reliable and informative. Second, I find no evidence that earnings are more value relevant when the proportion of IC personnel among the firm's employees is greater. This implies that a numerical increase in IC personnel alone does not provide greater assurance on the reliability of earnings. Taken together, my findings indicate that the firms with a suitable control environment composed of more qualified IC personnel is more likely to provide reliable financial reporting.

This study contributes to the literature in several ways. First, this study extends the literature on IC by exploring the association between IC environment and the value relevance of its accounting information. I provide compelling evidence that a suitable control environment is positively related to the value relevance of earnings by using data unique to Korean listed firms, which are required to disclose the number of IC personnel and their average work experience. Second, my findings suggest that a suitable control environment represented by the personnel integrity/ethical values, competence, and authority/ responsibility can be attributed to the quality rather than the quantity of IC personnel; this supports the guidance of Deloitte that emphasizes the use of knowledgeable personnel to ascertain the effectiveness of IC on financial reporting. This study has important implications for managers, auditors, regulators, and capital market participants who are interested in assessing effectiveness of IC, reliability of financial reporting, and the value relevance of earnings.

The remainder of the paper proceeds as follows. Section 1 describes the relevant literature and proposes the hypotheses. Section 2 introduces the study's research method and the model used to test the hypotheses. Section 3 presents the empirical results. Finally, last section concludes the paper.

\section{LITERATURE REVIEW AND DEVELOPMENT OF HYPOTHESES}

\subsection{Institutional background}

In the United States, the 2002 Sarbanes-Oxley Act (SOX) was enacted to protect investors by improving transparency and reliability of financial reporting. It was in response to a series of corporate accounting fraud in the late 1990s. Section 404 of the SOX mandates listed firms to establish, maintain, and assess an IC system that provides reasonable assurance regarding the reliability of financial reporting. It also requires external auditors to provide an independent opinion on the adequacy of ICs for financial reporting. Following the passage of SOX in the United States, the Korean government released guidelines and regulations that re- quire firms to establish and maintain an effective IC system for reliable financial reporting. In particular, the guidelines, which were released by the Financial Supervisory Service in 2002, state that Korean listed firms should disclose reports on the operation of their IC system that contains detailed information about the number of IC personnel and their average work experience. This is presumed to reflect the expectation that the number and/or work experience of IC personnel is one of the important determinants of IC effectiveness on financial reporting.

\subsection{Literature review}

Because Section 404 of the SOX requires firms to report the effectiveness of IC on financial reporting, researchers have investigated the association between the weakness of IC and the quality of financial reporting. By using data on 705 firms that 
disclosed at least one material weakness in IC from 2002 to 2005, Doyle et al. (2007) find that material weaknesses are associated with lower quality of financial reporting; following the approach developed by Dechow and Dichev (2002), they measure the quality of financial reporting on the basis of accruals that are not realized as cash flows. Similarly, Ashbaugh-Shaife et al. (2008) find that firms with IC deficiencies exhibit lower quality of accruals, reflected in greater accrual noise and abnormal accruals than firms not reporting IC problems. Chan et al. (2008) also report that firms with IC weaknesses are more likely to engage in accrual-based earnings management than firms without them.

Some studies on IC focus on the factors leading to IC weaknesses. For instance, Ge and McVay (2005) examine the disclosures of material weaknesses for 261 companies from 2002 to 2004 and find that those related to IC are usually associated with insufficient allocation of qualified accounting personnel for accounting controls. Based on a review of disclosures on the remediation actions taken in response to the weaknesses in IC, Fargher and Gramling (2005) document that among the most frequently mentioned remediation actions are the appointment of new staff and improvement in training.

Based on prior studies, Choi et al. (2013) focus on human resource issues and verify the direct association between investment in IC personnel and IC weaknesses. By investigating IC personnel data unique to Korea during 2005-2008, they find that the proportion of IC personnel and the change in this proportion within the firm and several key departments are negatively associated with disclosure of IC weaknesses. They also find that a change in IC personnel is positively related to the likelihood of remediation of IC weaknesses. Their findings suggest that firms with greater investment in IC personnel are more likely to improve the efficiency of their IC systems. Shin et al. (2016) extend the literature by investigating the relationship between investment in IC personnel and the efficiency of the audit procedure. Using 2,702 firm-year observations of Korean listed firms during 20062010 , they find that the average work experience of
IC personnel reduces audit reporting lag, a proxy for the timeliness of financial reporting. However, they find no relation between the ratio of IC personnel and audit reporting lag, suggesting that an increase in the number of IC personnel does not necessarily lead to efficient audits. Their findings indicate that the qualitative aspect of IC personnel is one of the important determinants of timely financial reporting, because more experienced IC personnel can improve the efficiency of the audit procedure.

\subsection{Hypotheses development}

It is well known that earnings are reflected in the stock price, because it captures and summarizes the economic performance that determines a firm's value (Beaver, 1998; Francis \& Schipper, 1999; Ohlson, 1995; Penman, 1998) ${ }^{1}$. The earnings become more value relevant when they are more reliable; this is because the market would perceive the earnings reported in higher quality of financial reporting to be more useful in evaluating the firm value, and thus place more reliance on them in the valuation process (Francis $\& \mathrm{Ke}, 2006$; Frankel et al., 2002). In other words, the value relevance of earnings is influenced by the market's perception of the reliability of financial reporting.

To provide reasonable assurance for the reliability of financial reporting to market participants, listed firms are required to establish an effective IC system under Section 404 of the SOX. IC system can be effectively operated under a suitable control environment, which is founded on the personnel integrity/ethical values, competence, and authority/responsibility. The level of suitable control environment is closely related to the quantity and quality of IC personnel for the following reasons. First, in guidance to auditors on audit considerations, the PCAOB states that the loss of employees integral to IC function may increase the risk of deficiencies in IC over financial reporting owing to the lack of segregation of duties or effective controls (PCAOB, 2008). Choi et al. (2013) also mention that the number of IC personnel is an important determinant of the effectiveness of an IC system. An effective IC system can prevent and

1 Value relevance of earnings is defined as earnings reflected in the stock price. 
detect fraud that could result in material misstatements in financial statements in a timely manner. Thus, the management who value the personnel integrity/ethical values, competence, and authority/responsibility would establish a solid control environment through the allocation of sufficient number of employees. However, the quantity of IC personnel does not necessarily guarantee a suitable IC environment. For example, an increase in the number of IC personnel who lack proper knowledge and training would rather deteriorate the effective controls by making communication slow and the reporting procedure complicated (Shin et al., 2016).

Second, a suitable control environment, represented by the personnel integrity/ethical values, competence, and authority/responsibility can be established by allocation of qualified IC personnel. Ge and McVay (2005) find that material weaknesses in IC are related to the lack of qualified accounting personnel, thereby leading to late identification and resolution of certain matters related to accounting and disclosure and failure to perform timely and effective reviews. A publication from Deloitte encourages the use of knowledgeable personnel with appropriate skills in monitoring activities to make sure that ICs are operating effectively (Deloitte, 2013). In this vein, the Korean Sarbanes-Oxley Act (K-SOX) mandates listed firms to disclose a report on the operation of their IC system that contains information about the number of IC personnel, as well as their average work experience $^{2}$. In addition, qualified IC personnel with more work experience can implement effective communication channels based on their understanding of a firm's structure, accounting procedures, and relevant laws/regulations, thereby leading to higher quality of financial reporting. Thus, I hypothesize that the value relevance of earnings will be positively associated with a suitable IC environment, measured by the quantity and quality of IC personnel ${ }^{3}$.

\section{Hypothesis: The value relevance of earnings will be positively associated with a suitable IC environment.}

\section{RESEARCH DESIGN}

\subsection{Model specifications}

For the value relevance of earnings, I apply a typical regression model to investigate the statistical association between stock returns and change in earnings ${ }^{4}$. In model 1 , market-adjusted return over 12 months, $R E T$, is regressed on the change in earnings before $\operatorname{tax}(\Delta E)$. The coefficient of $\Delta E$ captures the value relevance of earnings. The level of suitable control environment is measured by the change in the ratio of IC personnel to total employees $(\triangle I C 1)$ and the change in the average work experience of a firm's IC personnel $(\triangle I C 2)$.

To verify the hypothesis, I partition the total sample into two subgroups by ranking observations based on $\triangle I C 1(\triangle I C 2)$ - one consisting of firms above the $5^{\text {th }}$ quintile (referred to as "TOP" subgroup) and the other of firms below the $1^{\text {st }}$ quintile (referred to as "BOTTOM" subgroup). The TOP subgroup is considered as the firms with the highest level of control environment, and the BOTTOM subgroup is considered as those with the lowest. I then estimate regression model 1 for each subgroup. If the value relevance of earnings is positively associated with the high level of control environment, the coefficient of $\triangle E$ in the TOP subgroup is expected to be greater than that of the BOTTOM subgroup.

2 K-SOX, which is the Korean equivalent of SOX, is a set of regulations on the IC system in Korean listed companies.

3 In Korea, external auditors evaluate the effectiveness of internal control system of firms and express their review opinion under K-SOX. Thus, the disclosure of internal control weakness would be used as a good proxy of a suitable control environment. However, unfortunately, I cannot use this proxy for the following reasons. First, the relation between internal control weakness and the quality of earnings/market reaction is already tested by other studies. Prior studies have documented that internal control weakness is negatively related to the quality of earnings (Ashbaugh-Skaife et al., 2008; Chan et al., 2008; Doyle et al., 2007). It is also documented that market reacts negatively to the disclosure of internal control weakness (Ashbaugh-Skaife et al., 2009; Beneish et al., 2008; Hammersley et al., 2008). Second, the ratio of firms reporting internal control weakness is quite low. According to Lee (2015), the firms that are reported to have internal control weakness account for only about $3 \%$ of the total firms sampled during the period from 2005 to 2010 . It means that the level of a suitable control environment in most of firms without internal control weakness is not precisely measured by this proxy.

4 Value relevance is usually measured as the statistical association between accounting information and stock price/returns. In this study, I focus on the value relevance of earnings, which is among the most representative accounting information on firms' economic performance and widely used by market participants. 


$$
\begin{aligned}
& R E T=\beta_{0}+\beta_{1} \Delta E+\beta_{2} S I Z E+\beta_{3} L E V+ \\
& +\beta_{4} R O A+\beta_{5} L O S S+\beta_{6} G R O W T H+ \\
& +\beta_{7} S T D S A L E S+\beta_{8} M T B+\beta_{9} O W N+ \\
& +\beta_{10} F O R+\beta_{11} \sum Y R+\beta_{12} \sum I N D+\varepsilon .
\end{aligned}
$$

For more sophisticated analysis, I develop moderated regression models 2,3 , and $4 . \triangle I C 1$ or $\triangle I C 2$ is used as a moderator variable to test whether it alters the value relevance of earnings (relationship between $\triangle E$ and $R E T)^{5}$. The variables of interest are the interaction terms between $\triangle E$ and $\triangle I C 1$ (or $\triangle I C 2$ ). They are added to model 1 to analyze whether the value relevance of earnings is affected by the level of suitable IC environment, measured by the change in the ratio of IC personnel $(\triangle I C 1)$ and the change in their average work experience $(\triangle I C 2)$ in models 2 and 3, respectively. In model 4 , both $\triangle I C 1$ and $\triangle I C 2$ are included to test my hypotheses after controlling for their effect on each other.

$$
\begin{aligned}
& R E T=\beta_{0}+\beta_{1} \Delta E+\beta_{2} \Delta I C 1+ \\
& +\beta_{3} \Delta E \cdot \Delta I C 1+\beta_{4} S I Z E+\beta_{5} L E V+ \\
& +\beta_{6} R O A+\beta_{7} L O S S+\beta_{8} G R O W T H+ \\
& +\beta_{9} S T D S A L E S+\beta_{10} M T B+ \\
& +\beta_{11} O W N+\beta_{12} F O R+\beta_{13} \sum Y R+ \\
& +\beta_{14} \sum I N D+\varepsilon,
\end{aligned}
$$

$$
\begin{aligned}
& R E T=\beta_{0}+\beta_{1} \Delta E+\beta_{2} \Delta I C 2+ \\
& +\beta_{3} \Delta E \cdot \Delta I C 2+\beta_{4} S I Z E+\beta_{5} L E V+ \\
& +\beta_{6} R O A+\beta_{7} L O S S+\beta_{8} G R O W T H+ \\
& +\beta_{9} S T D S A L E S+\beta_{10} M T B+\beta_{11} O W N \\
& +\beta_{12} F O R+\beta_{13} \sum Y R+\beta_{14} \sum I N D+\varepsilon,
\end{aligned}
$$

The initial sample consists of companies listed on the Korea Stock Exchange during 2005-2010 ${ }^{7}$. To ensure the homogeneity of the analyzed companies, I exclude a sample of firms in the financial industry and firms whose accounting year does not

$$
\begin{aligned}
& R E T=\beta_{0}+\beta_{1} \Delta E+\beta_{2} \Delta I C 1+\beta_{3} \Delta I C 2+ \\
& +\beta_{4} \Delta E \cdot \Delta I C 1+\beta_{5} \Delta E \cdot \Delta I C 2+ \\
& +\beta_{6} \Delta I C 1 \cdot \Delta I C 2+\beta_{7} S I Z E+\beta_{8} L E V+ \\
& +\beta_{9} R O A+\beta_{10} L O S S+\beta_{11} G R O W T H+ \\
& +\beta_{12} S T D S A L E S+\beta_{13} M T B+\beta_{14} O W N+ \\
& +\beta_{15} F O R+\beta_{16} \sum Y R+\beta_{17} \sum I N D+\varepsilon .
\end{aligned}
$$

To control for the effects of other factors on the stock return, I include variables, such as firm size $(S I Z E)$, leverage $(L E V)$, return on asset $(R O A)$, binary indicator of operating income (LOSS), sales growth (GROWTH), variability of sales (STDSALES), market-to-book value (MTB), and proportion of ownership held by the largest shareholder $(O W N)$, as well as that held by foreign investors (FSH). Collins and Kothari (1989) and Fama and French (1995) argue that firm size $(S I Z E)$ and market-to-book value $(M T B)$ are significantly related to the stock return. The leverage $(L E V)$ is used as a proxy of the riskiness of debt or default risk, which is negatively related to the stock return (Dhaliwal, 1991). As prior studies consider various financial ratios to estimate stock prices, ROA, GROWTH, and LOSS are added to the models (Fama \& French, 2006; Nissim \& Penman, 2001). Also, sales variability (STDSALES) is used as a proxy of business risk (Reilly \& Brown, 2011; Rattiner, 2008) ${ }^{6}$. To control for the effects of ownership structure and external monitoring by foreign investors, $O W N$ and $F S H$ are included in the models (Choe et al., 1999; Lemmon \& Lins, 2003).

\subsection{Sample selection procedure}

dustry and firms whose accounting year does not

5 In a moderated regression analysis, a moderator variable can be both categorical and continuous (Baron \& Kenny, 1986). When the moderator variable is continuous, the coefficient of interaction term $(\Delta E \cdot \Delta I C 1$ or $\Delta E \cdot \Delta I C 2)$ represents that the slope for the regression of $R E T$ on $\triangle E$ varies according to the level of the moderator variable ( $\triangle I C 1$ or $\triangle I C 2)$. More precisely, the positive coefficient of interaction term $(\Delta E \cdot \Delta I C 1$ or $\Delta E \cdot \Delta I C 2)$ implies that the positive effect of $\Delta \mathrm{E}$ on RET (value relevance of earnings) is strengthened by the level of $\triangle I C 1$ or $\triangle I C 2$.

6 STDSALES denotes the variability of sales, calculated based on annual data (Francis et al., 2004).

7 Following the government's roadmap to adopt the International Financial Reporting Standards (IFRS), Korean listed firms were required to prepare their financial statements under Korean International Financial Reporting Standards (K-IFRS) from the beginning of 2011. Prior to the adoption of IFRS, financial statements were prepared in accordance with the Korean Generally Accepted Accounting Principles (K-GAAP). Thus, I use data until 2010 to rule out the effect of the change in accounting standards on the value relevance of earnings. 
end in December. I collected data on the IC personnel of firms from their annual reports in the Financial Supervisory Service website (http://dart. fss.or.kr). The stock price and financial data are obtained from the KISVALUE database (equivalent to the CRSP in the United States). Firms without appropriate IC personnel data are excluded; this removes 393 firm-year observations. I also eliminate 144 firm-year observations for which stock price and financial data are not available in the KISVALUE database. My final sample consists of 1,834 firm-year observations. The sample selection process is described in Table 1.

Table 1. Sample selection procedure

\begin{tabular}{|c|c|}
\hline Procedures & Number \\
\hline $\begin{array}{l}\text { Observations of companies listed on the Korea } \\
\text { Stock Exchange during 2005-2010, excluding firms } \\
\text { whose accounting year does not end in December } \\
\text { and firms in the financial industry }\end{array}$ & 2,371 \\
\hline \multicolumn{2}{|l|}{ Less: } \\
\hline Missing observations in obtaining IC personnel data & 393 \\
\hline $\begin{array}{l}\text { Observations whose stock return and other } \\
\text { financial data are not available in the KISVALUE } \\
\text { database }\end{array}$ & 144 \\
\hline Final sample firm-years & 1,834 \\
\hline
\end{tabular}

\section{EMPIRICAL RESULTS}

\subsection{Descriptive statistics and correlation analysis}

Table 2 presents the descriptive statistics for the variables used in the tests. To rule out the effects of outliers, winsorize the top and bottom $1 \%$ of the observations for all continuous variables. The mean (median) values of market-adjusted stock return (RET) and change in earnings before tax $(\Delta E)$ are $0.045(0.002)$ and 0.019 (0.006), respectively. The mean (median) value of the quantitative measure of IC personnel - the ratio of IC personnel to the total number of employees in the firm (IC1) - is 0.077 (0.033); this implies that, on average, the percentage of employees in charge of the implementation of IC is approximately $7.7 \%$. The mean (median) value of the qualitative measure of IC personnel, IC2, calculated by taking the $\log$ of one plus average work experience in months is 4.336 (4.516). The mean (median) values of the change in the ratio of IC personnel $(\triangle I C 1)$ and the change in work experience $(\triangle I C 2)$ are 0.003 $(0.000)$ and -0.002 (0.052), respectively.

For the control variables, the mean (median) values of firm size (SIZE), debt ratio (LEV), and market-to-book value (MTB) are 19.664 (19.380), 0.883 (0.746), and 1.061 (0.776), respectively. The sample firms' return on asset $(R O A)$ is about 0.034 and the proportion of observations showing negative earnings before tax (LOSS) is about $16.8 \%$. The mean (median) values of change in sales $(G R O W T H)$ and variability of sales over the 3 years (STDSALES) are $0.098(0.084)$ and 0.399 (0.227), respectively.

Table 2. Descriptive statistics of variables

\begin{tabular}{|c|c|c|c|c|c|c|}
\hline Variables & $\mathbf{N}$ & Mean & Median & SD & MIN & MAX \\
\hline RET & 1,834 & 0.045 & 0.002 & 0.410 & -0.810 & 1.399 \\
\hline$E$ & 1,834 & 0.103 & 0.100 & 0.203 & -0.679 & 0.722 \\
\hline$\Delta E$ & 1,834 & 0.019 & 0.006 & 0.202 & -0.721 & 0.743 \\
\hline $1 C 1$ & 1,834 & 0.077 & 0.033 & 0.159 & 0.000 & 1.000 \\
\hline $1 C 2$ & 1,834 & 4.336 & 4.516 & 1.057 & 0.000 & 5.971 \\
\hline$\triangle / C 1$ & 1,834 & 0.003 & 0.000 & 0.043 & -0.154 & 0.302 \\
\hline$\triangle / C 2$ & 1,834 & -0.002 & 0.052 & 0.391 & -2.079 & 1.156 \\
\hline SIZE & 1,834 & 19.664 & 19.380 & 1.480 & 17.049 & 23.915 \\
\hline LEV & 1,834 & 0.883 & 0.746 & 0.632 & 0.041 & 2.769 \\
\hline$R O A$ & 1,834 & 0.034 & 0.037 & 0.071 & -0.278 & 0.195 \\
\hline LOSS & 1,834 & 0.168 & 0.000 & 0.374 & 0.000 & 1.000 \\
\hline GROWTH & 1,834 & 0.098 & 0.084 & 0.283 & -0.863 & 1.348 \\
\hline STDSALES & 1,834 & 0.399 & 0.227 & 0.504 & 0.007 & 2.965 \\
\hline MTB & 1,834 & 1.061 & 0.776 & 0.876 & 0.177 & 5.124 \\
\hline OWN & 1,834 & 0.386 & 0.405 & 0.200 & 0.000 & 0.823 \\
\hline FSH & 1,834 & 0.104 & 0.041 & 0.141 & 0.000 & 0.637 \\
\hline
\end{tabular}

Note: RET - market-adjusted stock return over 12 months; beginning in the fourth month after the end of fiscal year $t-1$ and ending 3 months after the end of fiscal year $t ; E-$ earnings before tax, deflated by the market value of equity at the beginning of fiscal year $t ; \Delta E$ - change in $E$; ICI - ratio of IC personnel to the total number of employees in the firm; $\triangle I C 1$ - change in IC1; IC2 - log of one plus average work experience of the IC personnel in months; $\triangle I C 2$ - change in IC2; SIZE - log of total assets; $L E V$ - total liabilities divided by total assets; $R O A$ - return on assets; LOSS - 1 if pre-tax book income is negative, and 0 otherwise; GROWTH - change in sales, scaled by lagged sales; STDSALES - variability of sales over a 3-year period; standard deviation of sales from fiscal year $t-3$ to fiscal year $t$, scaled by the market value of equity at the beginning of fiscal year $t$; MTB - market to book ratio; OWN - proportion of ownership held by the largest shareholder (including family members and other related parties) of the firm; FSH - proportion of ownership held by foreign investors. 
Table 3. Correlations of variables

\begin{tabular}{|c|c|c|c|c|c|c|c|c|c|c|c|c|c|}
\hline Variables & $R E T$ & $\Delta E$ & $\Delta / C 1$ & $\Delta / C 2$ & SIZE & LEV & $R O A$ & LOSS & GROWTH & TD SALES & MTB & OWN & $F S H$ \\
\hline \multirow{2}{*}{ RET } & 1.0000 & 0.2364 & -0.0250 & -0.0069 & 0.0520 & 0.0440 & 0.2278 & -0.1620 & 0.1451 & 0.0992 & 0.2310 & 0.0215 & -0.0039 \\
\hline & - & $<0.0001$ & 0.2848 & 0.7679 & 0.0258 & 0.0596 & $<0.0001$ & $<0.0001$ & $<0.0001$ & $<0.0001$ & $<0.0001$ & 0.3582 & 0.8661 \\
\hline \multirow{2}{*}{$\Delta E$} & - & 1.0000 & -0.0314 & 0.0090 & -0.0082 & -0.0755 & 0.4118 & -0.3752 & 0.2235 & 0.0949 & 0.0659 & 0.0218 & 0.0208 \\
\hline & - & - & 0.1784 & 0.6996 & 0.7244 & 0.0012 & $<0.0001$ & $<0.0001$ & $<0.0001$ & $<0.0001$ & 0.0048 & 0.3510 & 0.3738 \\
\hline \multirow{2}{*}{$\Delta / C 1$} & - & - & 1.0000 & 0.0624 & -0.0431 & -0.0610 & -0.0378 & 0.0409 & -0.2699 & 0.0354 & -0.0272 & 0.0121 & -0.0215 \\
\hline & - & - & - & 0.0075 & 0.0649 & 0.0089 & 0.1056 & 0.0797 & $<0.0001$ & 0.1300 & 0.2445 & 0.6057 & 0.3572 \\
\hline \multirow{2}{*}{$\Delta / C 2$} & - & - & - & 1.0000 & -0.0126 & -0.0285 & 0.0028 & -0.0121 & -0.0284 & 0.0150 & -0.0055 & -0.0038 & -0.0183 \\
\hline & - & - & - & - & 0.5893 & 0.2233 & 0.9048 & 0.6059 & 0.2241 & 0.5196 & 0.8128 & 0.8695 & 0.4330 \\
\hline \multirow{2}{*}{ SIZE } & - & - & - & - & 1.0000 & 0.1677 & 0.2253 & -0.1587 & 0.0865 & -0.0547 & 0.2041 & -0.1491 & 0.4655 \\
\hline & - & - & - & - & - & $<0.0001$ & $<0.0001$ & $<0.0001$ & 0.0002 & 0.0192 & $<0.0001$ & $<0.0001$ & $1<0.0001$ \\
\hline \multirow{2}{*}{ LEV } & - & - & - & - & - & 1.0000 & -0.2631 & 0.1518 & 0.1279 & 0.2178 & 0.1670 & -0.0635 & -0.1059 \\
\hline & - & - & - & - & - & - & $<0.0001$ & $<0.0001$ & $<0.0001$ & $<0.0001$ & $<0.0001$ & 0.0065 & $<0.0001$ \\
\hline \multirow{2}{*}{$R O A$} & - & - & - & - & - & - & 1.0000 & -0.6963 & 0.1657 & -0.0528 & 0.2066 & 0.0363 & 0.2516 \\
\hline & - & - & - & - & - & - & - & $<0.0001$ & $<0.0001$ & 0.0239 & $<0.0001$ & 0.1198 & $<0.0001$ \\
\hline \multirow[b]{2}{*}{ LOSS } & - & - & - & - & - & - & - & 1.0000 & -0.1425 & 0.0057 & -0.0900 & -0.0446 & -0.1230 \\
\hline & - & - & - & - & - & - & - & - & $<0.0001$ & 0.8067 & 0.0001 & 0.0563 & $<0.0001$ \\
\hline \multirow{2}{*}{ GROWTH } & - & - & - & - & - & - & - & - & 1.0000 & 0.0262 & 0.0814 & -0.0108 & 0.0231 \\
\hline & - & - & - & - & - & - & - & - & - & 0.2619 & 0.0005 & 0.6455 & 0.3223 \\
\hline \multirow{2}{*}{$\begin{array}{l}\text { STD } \\
\text { SALES }\end{array}$} & - & - & - & - & - & - & - & - & - & 1.0000 & -0.1668 & 0.0144 & -0.1468 \\
\hline & - & - & - & - & - & - & - & - & - & - & $<0.0001$ & 0.5383 & $<0.0001$ \\
\hline \multirow{2}{*}{ MTB } & - & - & - & - & - & - & - & - & - & - & 1.0000 & -0.1700 & 0.2389 \\
\hline & - & - & - & - & - & - & - & - & - & - & - & $<0.0001$ & $<0.0001$ \\
\hline \multirow{2}{*}{ OWN } & - & - & - & - & - & - & - & - & - & - & - & 1.0000 & -0.1878 \\
\hline & - & - & - & - & - & - & - & - & - & - & - & - & $<0.0001$ \\
\hline \multirow{2}{*}{ FSH } & - & - & - & - & - & - & - & - & - & - & - & - & 1.0000 \\
\hline & - & - & - & - & - & - & - & - & - & - & - & - & - \\
\hline
\end{tabular}

Note: The variables are defined as in Table 2.

Table 3 presents the Pearson correlations for the variables used in the tests. The change in earnings before $\operatorname{tax}(\Delta E)$ is positively correlated with market-adjusted stock return $(\triangle R E T)$, which confirms that earnings, used to assess firm value, are reflected in the stock price. However, the change in the ratio of IC personnel $(\triangle I C 1)$ or change in work experience of IC personnel $(\triangle I C 2)$ is not significantly correlated with market-adjusted stock return $(\triangle R E T)$. Among the control variables, the firm size (SIZE), debt ratio ( $L E V)$, change in sales (GROWTH), variability of sales (STDSALES), and market-to-book value $(M T B)$ are positively correlated with market-adjusted return $(\triangle R E T)$, whereas an indicator variable measuring loss (LOSS) is negatively correlated with market-adjusted stock return $(\triangle R E T)$.

\subsection{Main regression results}

Table 4 presents the results of model 1 estimated for TOP and BOTTOM subgroups. In specific, Panel A of Table 4 provides the results of model 1 estimated for two subgroups divided based on $\triangle I C 1$. The coefficient of $\Delta E$ is not statistically significant for BOTTOM subgroup, while it is significantly positive for TOP subgroup. It suggests that the value relevance of earnings is observed only in the firms with the highest level of suitable control environment, measured by the allocation of more IC personnel. Panel B of Table 4 provides the results of model 1 estimated for two subgroups divided based on $\triangle I C 2$. The coefficients of $\triangle E$ are both significantly positive for two subgroups, but the coefficient of $\Delta E$ and its significance level for 
Table 4. Analysis on the value relevance of earnings for subgroups

\begin{tabular}{|c|c|c|c|c|c|c|}
\hline \multicolumn{7}{|c|}{ Panel A. The results of model 1 estimated for two subgroups divided based on $\Delta / C 1$} \\
\hline \multirow{2}{*}{ Variables } & \multicolumn{3}{|c|}{ ВOTTOM subgroup } & \multicolumn{3}{|c|}{ TOP subgroup } \\
\hline & Coefficient & t-stat & VIF & Coefficient & t-stat & VIF \\
\hline Intercept & -0.521 & -1.35 & 0.000 & -0.338 & -0.94 & 0.000 \\
\hline$\Delta E$ & 0.123 & 1.05 & 1.476 & 0.274 & $2.62 * * *$ & 1.369 \\
\hline SIZE & 0.005 & 0.26 & 1.534 & -0.010 & -0.53 & 1.419 \\
\hline$\angle E V$ & 0.020 & 0.49 & 1.659 & -0.045 & -1.24 & 1.392 \\
\hline$R O A$ & 0.961 & $2.15^{* *}$ & 2.906 & 1.111 & $2.77^{* * *}$ & 2.715 \\
\hline LOSS & -0.058 & -0.72 & 2.345 & 0.044 & 0.59 & 2.428 \\
\hline GROWTH & 0.099 & 1.68 & 1.258 & 0.085 & 1.19 & 1.325 \\
\hline STDSALES & 0.082 & 2.23 & 1.231 & 0.105 & $2.70 * * *$ & 1.219 \\
\hline MTB & 0.152 & $5.19^{* * *}$ & 1.428 & 0.216 & $7.09 * * *$ & 1.363 \\
\hline OWN & 0.228 & $2.07 * *$ & 1.163 & 0.257 & $2.16^{* *}$ & 1.120 \\
\hline FSH & -0.281 & -1.48 & 1.374 & -0.285 & -1.54 & 1.298 \\
\hline$Y R$ & \multicolumn{3}{|c|}{ Included } & \multicolumn{3}{|c|}{ Included } \\
\hline IND & \multicolumn{3}{|c|}{ Included } & \multicolumn{3}{|c|}{ Included } \\
\hline$R^{2}$-Adj & \multicolumn{3}{|c|}{0.172} & \multicolumn{3}{|c|}{0.2175} \\
\hline N & \multicolumn{3}{|c|}{366} & \multicolumn{3}{|c|}{367} \\
\hline \multicolumn{7}{|c|}{ Panel B. The results of model 1 estimated for two subgroups divided based on $\triangle I C 2$} \\
\hline \multirow{2}{*}{ Variables } & \multicolumn{3}{|c|}{ BOTTOM subgroup } & \multicolumn{3}{|c|}{ TOP subgroup } \\
\hline & Coefficient & t-stat & VIF & Coefficient & t-stat & VIF \\
\hline Intercept & -0.909 & $-2.91 * * *$ & 0.000 & -0.693 & $-2.12 * *$ & 0.000 \\
\hline$\Delta E$ & 0.251 & $2.11^{* *}$ & 1.500 & 0.401 & $3.73 * * *$ & 1.469 \\
\hline SIZE & 0.028 & $1.76^{*}$ & 1.662 & 0.010 & 0.62 & 1.714 \\
\hline$\angle E V$ & -0.074 & $-2.01^{* *}$ & 1.545 & 0.041 & 1.07 & 1.445 \\
\hline$R O A$ & 0.726 & 1.54 & 2.783 & 0.824 & $2.07^{* *}$ & 2.573 \\
\hline LOSS & 0.024 & 0.33 & 2.157 & 0.015 & 0.18 & 2.442 \\
\hline GROWTH & 0.093 & 1.31 & 1.283 & 0.012 & 0.16 & 1.178 \\
\hline STDSALES & 0.156 & $4.08^{* * *}$ & 1.177 & 0.148 & $3.45^{* * *}$ & 1.251 \\
\hline MTB & 0.159 & $6.77^{* * *}$ & 1.474 & 0.095 & $3.25 * * *$ & 1.395 \\
\hline OWN & 0.086 & 0.86 & 1.167 & 0.461 & $4.24^{* * *}$ & 1.178 \\
\hline FSH & -0.575 & $-3.38^{* * *}$ & 1.575 & 0.034 & 0.18 & 1.664 \\
\hline$Y R$ & \multicolumn{3}{|c|}{ Included } & \multicolumn{3}{|c|}{ Included } \\
\hline IND & \multicolumn{3}{|c|}{ Included } & \multicolumn{3}{|c|}{ Included } \\
\hline$R^{2}-A d j$ & \multicolumn{3}{|c|}{0.1893} & \multicolumn{3}{|c|}{0.23436} \\
\hline N & \multicolumn{3}{|c|}{366} & \multicolumn{3}{|c|}{367} \\
\hline
\end{tabular}

Notes: The variables are defined as in Table $2 .^{*}, * *$, and $* * *$ indicate significance levels at the $10 \%, 5 \%$, and $1 \%$, respectively, based on two-tailed tests.

TOP subgroup are higher than those of BOTTOM subgroup. It implies that the value relevance of earnings is positively associated with the level of suitable control environment, measured by the allocation of more experienced IC personnel. To ensure that multicollinearity is not driving my results, I check for the variance inflation factor (VIF) in all empirical tests as there are highly correlated variables. The VIFs are all less than 3 , indicating that multicollinearity is not a serious concern in my analysis.
For more sophisticated analysis, I investigate the moderating effect of $\triangle I C 1(\triangle I C 2)$ on the value relevance of earnings by conducting a 3-step hierarchical regression analysis as follows:

$$
\begin{aligned}
& R E T=\beta_{0}+\beta_{1} \Delta E+\beta_{2} S I Z E+\beta_{3} L E V+ \\
& +\beta_{4} R O A+\beta_{5} L O S S+\beta_{6} \text { GROWTH }+ \\
& +\beta_{7} S T D S A L E S+\beta_{8} M T B+\beta_{9} O W N+ \\
& +\beta_{10} F O R+\beta_{11} \sum Y R+\beta_{12} \sum I N D+\varepsilon
\end{aligned}
$$

8 For the rest of analyses, I also have conducted a 3-step hierarchical regression and their results are unchanged. For brevity, only the result of step 3 regression is tabulated in the manuscript. 
$R E T=\beta_{0}+\beta_{1} \Delta E+\beta_{2} \Delta I C 1(\Delta I C 2)+$

$+\beta_{3} S I Z E+\beta_{4} L E V+\beta_{5} R O A+$

$+\beta_{6}$ LOSS $+\beta_{7}$ GROWTH +

$+\beta_{8} S T D S A L E S+\beta_{9} M T B+$

(step 2)

$+\beta_{10} O W N+\beta_{11} F O R+\beta_{12} \sum Y R+$

$+\beta_{13} \sum I N D+\varepsilon$,

$R E T=\beta_{0}+\beta_{1} \Delta E+\beta_{2} \Delta I C 1(\Delta I C 2)+$

$+\beta_{3} \Delta E \cdot \Delta I C 1(\triangle I C 2)+\beta_{4} S I Z E+$

$+\beta_{5} L E V+\beta_{6} R O A+\beta_{7} L O S S+$

$+\beta_{8}$ GROWTH $+\beta_{9}$ STDSALES +

$+\beta_{10} M T B+\beta_{11} O W N+\beta_{12} F O R+$

$+\beta_{13} \sum Y R+\beta_{14} \sum I N D+\varepsilon$.
The hierarchical results for the moderating effect of $\triangle I C 1(\triangle I C 2)$ are summarized in Table 5. Panel A of Table 5 shows that $\triangle I C 1$ has no moderating effect on the value relevance of earnings, because the introduction of interaction term $(\Delta E \cdot \Delta I C 1$ ) does not significantly increase $R^{2}$ and the coefficient of $\Delta E \cdot \Delta I C 1$ is not significant in step 3. On the other hand, Panel B of Table 5 reveals that $\triangle I C 2$ moderate the relationship between $\Delta E$ and $R E T$. In step 3 , the introduction of interaction term $(\Delta E \cdot \Delta I C 2)$ significantly increase $R^{2}$, and the coefficient of $\Delta E \cdot \Delta I C 2$ is positively significant at $5 \%$ level. The $R^{2}$ change is tested with an F-test $(p$-value $=0.049<0.5)$. The coefficient of moderator variable $(\triangle I C 2)$ is not significant, indicating that $\triangle I C 2$ is a pure moderator (Sharma et

Table 5. Analysis on the effect of IC environment on the value relevance of earnings

\begin{tabular}{|c|c|c|c|c|c|c|}
\hline \multicolumn{7}{|c|}{ Panel A. Model 2} \\
\hline \multirow{2}{*}{ Variables } & \multicolumn{2}{|c|}{ Step 1} & \multicolumn{2}{|c|}{ Step 2} & \multicolumn{2}{|c|}{ Step 3} \\
\hline & Coefficient & t-stat & Coefficient & t-stat & Coefficient & t-stat \\
\hline Intercept & -0.592 & $-4.19 * * *$ & -0.593 & $-4.20^{* * *}$ & -0.592 & $-4.19 * * *$ \\
\hline$\Delta E$ & 0.325 & $6.55^{* * *}$ & 0.324 & $6.53^{* * *}$ & 0.325 & $6.53^{* * *}$ \\
\hline$\triangle / C 1$ & - & - & 0.068 & 0.32 & 0.066 & 0.31 \\
\hline$\Delta E \cdot \Delta / C 1$ & - & - & - & - & -0.180 & -0.17 \\
\hline SIZE & 0.013 & $1.79 *$ & 0.013 & $1.79 *$ & 0.013 & $1.78^{*}$ \\
\hline LEV & -0.012 & -0.74 & -0.012 & -0.73 & -0.012 & -0.72 \\
\hline$R O A$ & 0.704 & $3.63 * * *$ & 0.703 & $3.63^{* * *}$ & 0.701 & $3.61^{* * *}$ \\
\hline LOSS & -0.020 & -0.60 & -0.020 & -0.60 & -0.020 & -0.61 \\
\hline GROWTH & 0.063 & $1.90 *$ & 0.066 & $1.92 *$ & 0.065 & 1.89 \\
\hline STDSALES & 0.125 & $6.65 * * *$ & 0.124 & $6.62 * * *$ & 0.124 & $6.62 * * *$ \\
\hline MTB & 0.126 & $10.86 * * *$ & 0.126 & $10.86^{* * *}$ & 0.127 & $10.85^{* * *}$ \\
\hline OWN & 0.091 & $2.01^{* *}$ & 0.091 & $2.01^{* *}$ & 0.090 & $2.00 * *$ \\
\hline FSH & -0.271 & $-3.65 * * *$ & -0.271 & $-3.64 * * *$ & -0.270 & $-3.64 * * *$ \\
\hline$Y R$ & \multicolumn{2}{|c|}{ Included } & \multicolumn{2}{|c|}{ Included } & \multicolumn{2}{|c|}{ Included } \\
\hline IND & \multicolumn{2}{|c|}{ Included } & \multicolumn{2}{|c|}{ Included } & \multicolumn{2}{|c|}{ Included } \\
\hline$R^{2}$ & \multicolumn{2}{|c|}{0.2046} & \multicolumn{2}{|c|}{0.2046} & \multicolumn{2}{|c|}{0.2047} \\
\hline$R^{2}$ change & \multicolumn{2}{|c|}{-} & \multicolumn{2}{|c|}{0.0000} & \multicolumn{2}{|c|}{0.0001} \\
\hline \multicolumn{7}{|c|}{ Panel B. Model 3} \\
\hline \multirow{2}{*}{ Variables } & \multicolumn{2}{|c|}{ Step 1} & \multicolumn{2}{|c|}{ Step 2} & \multicolumn{2}{|c|}{ Step 3} \\
\hline & Coefficient & t-stat & Coefficient & t-stat & Coefficient & t-stat \\
\hline Intercept & -0.592 & $-4.19 * * *$ & -0.592 & $-4.19 * * *$ & -0.599 & $-4.24 * * *$ \\
\hline$\Delta E$ & 0.325 & $6.55 * * *$ & 0.325 & $6.55^{* * *}$ & 0.319 & $6.43 * * *$ \\
\hline$\triangle I C 2$ & - & - & -0.003 & -0.12 & -0.002 & -0.07 \\
\hline$\triangle E \cdot \triangle I C 2$ & - & - & - & - & 0.222 & $1.97 * *$ \\
\hline SIZE & 0.013 & $1.79 *$ & 0.013 & $1.79 *$ & 0.013 & $1.82 *$ \\
\hline$\angle E V$ & -0.012 & -0.74 & -0.012 & -0.74 & -0.012 & -0.72 \\
\hline$R O A$ & 0.704 & $3.63^{* * *}$ & 0.704 & $3.63^{* * *}$ & 0.725 & $3.74 * * *$ \\
\hline LOSS & -0.020 & -0.60 & -0.020 & -0.60 & -0.018 & -0.54 \\
\hline GROWTH & 0.063 & $1.90^{*}$ & 0.063 & $1.90^{*}$ & 0.064 & $1.92 * *$ \\
\hline STDSALES & 0.125 & $6.65^{* * *}$ & 0.125 & $6.65^{* * *}$ & 0.126 & $6.69 * * *$ \\
\hline MTB & 0.126 & $10.86^{* * *}$ & 0.126 & $10.86^{* * *}$ & 0.126 & $10.85^{* * *}$ \\
\hline OWN & 0.091 & $2.01^{* *}$ & 0.091 & $2.01^{* *}$ & 0.092 & $2.04^{* *}$ \\
\hline FSH & -0.271 & $-3.65^{* * *}$ & -0.271 & $-3.65 * * *$ & -0.271 & $-3.65 * * *$ \\
\hline$Y R$ & \multicolumn{2}{|c|}{ Included } & \multicolumn{2}{|c|}{ Included } & \multicolumn{2}{|c|}{ Included } \\
\hline IND & & & & & & \\
\hline$R^{2}$ & & & & & & \\
\hline$R^{2}$ change & & & & & 0.0 & \\
\hline $\mathrm{N}$ & & & & & & \\
\hline
\end{tabular}

Notes: The variables are defined as in Table $2 . * * *$, and $* * *$ indicate significance levels at the $10 \%, 5 \%$, and $1 \%$, respectively, based on two-tailed tests. 
al., 1981). The results suggest that the earnings are more value relevant when the change in the average work experience of the IC personnel increases. This is in accordance with Ge and McVay (2005), who find that the lack of expertise in IC can lower the quality of financial reporting. In sum, the results imply that the value relevance of earnings increases as the level of suitable control environment increases, even though the positive association is observed only when the level of suitable control environment is assessed in perspective of the quality of IC personnel.

Table 6 presents the results of the analysis on the effect of IC environment on the value relevance of earnings, after controlling for the effect of the quantity and quality of IC personnel on each other. Column A of Table 6 provides the results of estimating model 3, which includes both $\triangle I C 1$ and $\triangle I C 2$. The coefficient of the interaction term be- tween $\Delta E$ and $\triangle I C 2(\Delta E \cdot \Delta I C 2)$ is still positive and statistically significant at the $5 \%$ level, whereas the coefficient of the interaction term between $\triangle E$ and $\triangle I C 1(\triangle E \cdot \Delta I C 1)$ is not. This confirms the work experience of IC personnel is a more important determinant of the improvement in the reliability of financial reporting through effective ICs than the number of IC personnel.

Additionally, I conduct the test by using an alternative measure of IC personnel quantity, $\triangle I C 1 \_N$, which measures the change in the ratio of IC personnel to total employees in the IC-related departments, such as accounting, finance, audit, and information technology. Column B of Table 6 reports the test results using the alternative measure. Overall, the results remain qualitatively similar when the alternative measure is applied. This confirms the view that a suitable control environment represented by the personnel integrity/ethical val-

Table 6. Analysis on the effect of IC environment on the value relevance of earnings after controlling for the effect of the quantity and quality of IC personnel on each other

\begin{tabular}{|c|c|c|c|c|c|c|}
\hline \multirow{2}{*}{ Variables } & \multicolumn{3}{|c|}{ Column A. Model 4} & \multicolumn{3}{|c|}{ Column B. Model 4 using $\Delta / C 1 \_N$} \\
\hline & Coefficient & t-stat & VIF & Coefficient & t-stat & VIF \\
\hline Intercept & -0.609 & $-4.31 * * *$ & 0.000 & -0.600 & $-4.24 * * *$ & 0.000 \\
\hline$\Delta E$ & 0.320 & $6.42 * * *$ & 1.372 & 0.318 & $6.37^{* * *}$ & 1.367 \\
\hline$\triangle / C 1$ & 0.092 & 0.44 & 1.105 & - & - & - \\
\hline$\Delta E \cdot \Delta / C 1$ & -0.199 & -0.19 & 1.028 & - & - & - \\
\hline$\triangle I C 2$ & 0.002 & 0.08 & 1.044 & - & - & - \\
\hline$\triangle E \cdot \Delta / C 2$ & 0.195 & $2.11^{* *}$ & 1.022 & - & - & - \\
\hline$\Delta / C 1 \cdot \Delta / C 2$ & 0.818 & $1.94^{*}$ & 1.031 & - & - & - \\
\hline$\triangle I C 1 \_N$ & - & - & - & 0.023 & 0.28 & 1.129 \\
\hline$\triangle E \cdot \triangle I C 1 \_N$ & - & - & - & 0.007 & 0.02 & 1.065 \\
\hline$\triangle I C 2$ & - & - & - & -0.007 & -0.32 & 1.044 \\
\hline$\triangle E \cdot \Delta / C 2$ & - & - & - & 0.191 & $2.05^{* *}$ & 1.041 \\
\hline$\triangle / C 1 \_N \cdot \triangle / C 2$ & - & - & - & -0.084 & -0.72 & 1.179 \\
\hline SIZE & 0.013 & $1.85^{*}$ & 1.519 & 0.013 & $1.83^{*}$ & 1.518 \\
\hline$L E V$ & -0.011 & -0.64 & 1.478 & -0.012 & -0.73 & 1.473 \\
\hline$R O A$ & 0.744 & $3.82 * * *$ & 2.561 & 0.724 & $3.72 * * *$ & 2.553 \\
\hline LOSS & -0.017 & -0.51 & 2.083 & -0.017 & -0.52 & 2.081 \\
\hline GROWTH & 0.064 & $1.88^{*}$ & 1.278 & 0.065 & $1.97 * *$ & 1.190 \\
\hline STDSALES & 0.125 & $6.66^{* * *}$ & 1.215 & 0.126 & $6.68^{* * *}$ & 1.214 \\
\hline MTB & 0.126 & $10.85^{* * *}$ & 1.407 & 0.126 & $10.83^{* * *}$ & 1.407 \\
\hline OWN & 0.090 & $2.01^{* *}$ & 1.105 & 0.094 & $2.07 * *$ & 1.106 \\
\hline FSH & -0.272 & $-3.67 * * *$ & 1.491 & -0.270 & $-3.64 * * *$ & 1.491 \\
\hline$Y R$ & \multicolumn{3}{|c|}{ Included } & \multicolumn{3}{|c|}{ Included } \\
\hline IND & \multicolumn{3}{|c|}{ Included } & \multicolumn{3}{|c|}{ Included } \\
\hline$R^{2}-A d j$ & \multicolumn{3}{|c|}{0.1950} & \multicolumn{3}{|c|}{0.1936} \\
\hline $\mathrm{N}$ & \multicolumn{3}{|c|}{1,834} & \multicolumn{3}{|c|}{1,834} \\
\hline
\end{tabular}

Notes: The variables (except $\triangle I C 1 N$ ) are defined as in Table $2 . *, * *$, and $* * *$ indicate significance levels at the $10 \%, 5 \%$, and $1 \%$, respectively, based on two-tailed tests. IC1_N - ratio of IC personnel to total employees in the IC - related departments, such as accounting, finance, audit, and information technology; $\triangle I C 1 \_N-$ change in IC1_N. 
Table 7. Additional analysis on the effect of IC environment on the value relevance of earnings using modified variables

\begin{tabular}{|c|c|c|c|c|c|c|}
\hline \multirow{2}{*}{ Variables } & \multicolumn{2}{|c|}{ Model 2} & \multicolumn{2}{|c|}{ Model 3} & \multicolumn{2}{|c|}{ Model 4} \\
\hline & Coefficient & t-stat & Coefficient & t-stat & Coefficient & t-stat \\
\hline Intercept & -0.499 & $-3.52 * * *$ & -0.493 & $-3.45 * * *$ & -0.516 & $-3.65^{* * *}$ \\
\hline$\Delta E$ & 0.351 & $6.97 * * *$ & 0.347 & $6.91 * * *$ & 0.348 & $6.91 * * *$ \\
\hline$\triangle / C 1$ & 0.145 & 0.68 & - & - & 0.174 & 0.82 \\
\hline$\Delta E \cdot \Delta / C 1$ & -0.261 & -0.25 & - & - & 0.002 & 0.06 \\
\hline$\triangle / C 2$ & - & - & -0.002 & -0.06 & -0.283 & -0.27 \\
\hline$\triangle E \cdot \Delta / C 2$ & - & - & 0.206 & $1.81^{*}$ & 0.214 & $1.88^{*}$ \\
\hline$\Delta / C 1 \cdot \Delta / C 2$ & - & - & - & - & 1.125 & $2.21^{* *}$ \\
\hline SIZE & 0.010 & 1.39 & 0.010 & 1.42 & 0.011 & 1.45 \\
\hline$L E V$ & 0.055 & 0.94 & 0.016 & 0.99 & 0.064 & 1.09 \\
\hline$R O A$ & 0.749 & $3.76^{* * *}$ & 0.770 & $3.90 * * *$ & 0.795 & $3.98 * * *$ \\
\hline LOSS & -0.018 & -0.53 & -0.016 & -0.48 & -0.015 & -0.43 \\
\hline GROWTH & 0.071 & $2.05^{* *}$ & 0.067 & $2.00 * *$ & 0.070 & $2.02 * *$ \\
\hline STDSALES & -0.004 & -0.07 & -0.003 & -0.06 & -0.004 & -0.07 \\
\hline MTB & 0.111 & $9.56 * * *$ & 0.110 & $9.51 * * *$ & 0.110 & $9.54 * * *$ \\
\hline OWN & 0.087 & $1.90 *$ & 0.088 & $1.92 *$ & 0.087 & $1.91^{*}$ \\
\hline FSH & -0.291 & $-3.86 * * *$ & -0.291 & $-3.88^{* * *}$ & -0.292 & $-3.89 * * *$ \\
\hline$Y R$ & \multicolumn{2}{|c|}{ Included } & \multicolumn{2}{|c|}{ Included } & \multicolumn{2}{|c|}{ Included } \\
\hline IND & \multicolumn{2}{|c|}{ Included } & \multicolumn{2}{|c|}{ Included } & \multicolumn{2}{|c|}{ Included } \\
\hline$R^{2}$-Adj & \multicolumn{2}{|c|}{0.1732} & \multicolumn{2}{|c|}{0.1745} & \multicolumn{2}{|c|}{0.1756} \\
\hline$N$ & \multicolumn{2}{|c|}{1,834} & \multicolumn{2}{|c|}{1,834} & \multicolumn{2}{|c|}{1,834} \\
\hline
\end{tabular}

Notes: The variables (except $\triangle I C 1, \triangle I C 2$, and STDSALES) are defined as in Table $2 . *, * *$, and $* * *$ indicate significance levels at the $10 \%, 5 \%$, and $1 \%$, respectively, based on two-tailed tests. VIFs are all less than $3 . \Delta / C 1$ - change in the ratio of IC personnel to total employees in the firm; the upper $10 \%$ of the observations for $I C 1$ is additionally winsorized; $\triangle I C 2$ - change in log of one plus average work experience of the IC personnel in years; STDSALES - sales variation over a 3-year period; standard deviation of sales from fiscal year $t-3$ to fiscal year $t$, scaled by the total assets at the beginning of fiscal year $t$.

ues, competence, and authority/responsibility can be attributed to the quality rather than the quantity of IC personnel.

\subsection{Additional analysis}

In this subsection, I conduct an additional analysis to mitigate the concerns on the variable related issues. First, the mean value of IC1 (0.077) is greater than the median value $(0.033)$ as shown in Table 1. It indicates that the distribution of $I C 1$ is skewed to the right because there are a few firms with extreme value of $I C 1$ in the sample. To rule out the effect of these outliers, I additionally winsorize the upper $10 \%$ of the observations for $I C 1^{9}$. Second, in the main analysis, IC2 is defined as the log of one plus average work experience of the IC personnel in months following prior studies (Choi et al., 2013; Shin et al., 2016). In an ad- ditional analysis, I use modified IC2 calculated by the $\log$ of 1 plus average work experience of the IC personnel in years. Third, I also use modified STDSALES, which is scaled by total assets instead of the market value of equity to eliminate the problem caused by the fluctuation of the market value of equity.

Table 7 presents the results of the analysis using the modified variables ( $\triangle I C 1, \triangle I C 2$, and STDSALES). The coefficient of the interaction term between $\triangle E$ and $\triangle I C 2$ is still positive and statistically significant, whereas the coefficient of the interaction term between $\Delta E$ and $\triangle I C 1(\Delta E \cdot \Delta I C 1)$ is not. Overall, Table 7 provides robust results and support the hypothesis that the value relevance of earnings is increased by the level of suitable control environment, established by qualified IC personnel with more work experience.

9 The upper $10 \%$ of values are set equal to the maximum value in the 90th percentile. After this winsorization, the mean (median) value of IC1 becomes 0.047 (0.033). 


\section{CONCLUSION}

This study examines the effect of IC environment on the value relevance of earnings. Specifically, I consider the quantity and quality of IC personnel to assess the level of suitable control environment which is determined by the personnel integrity/ethical values, competence, and authority/responsibility.

Using a sample of 1,834 firm-year observations of Korean listed companies covering 2005-2010, I find that earnings are more value relevant when the increase in work experience of the firm's IC personnel is greater. This suggests that the allocation of more experienced personnel to the IC function provides greater assurance on the reliability financial reporting. However, I do not find a significant association between the value relevance of earnings and the increase in the ratio of IC personnel. This indicates that simply adding more IC personnel does not provide greater assurance on the reliability of earnings. These results imply that the effectiveness of ICs on financial reporting is likely to be attributed to a suitable control environment, established by qualified IC personnel with more work experience. The limitation of this study is that I use the data during the period of financial crisis. However, this study provides compelling evidence that the value relevance of earnings is positively affected by qualitative investment in IC personnel by analyzing a set of data unique to Korean listed companies. Evidence from this study can help managers, auditors, regulators, and market participants better understand the determinants of effective ICs for financial reporting from a control environment perspective.

\section{REFERENCES}

1. Ashbaugh-Shaife, H., Collins, D., Kinney, W., \& Lafond, R. (2008). The effect of SOX internal control deficiencies and their remediation on accrual quality. The Accounting Review, 83(1), 217-250. https://doi. org/10.2308/accr.2008.83.1.217

2. Ashbaugh-Shaife, H., Collins, D. Kinney, W., \& Lafond, R. (2009). The effect of SOX internal control deficiencies on firm risk and cost of equity. Journal of Accounting Research, 47(1), 1-43. Retrieved from http://www.jstor.org/stable/25548010

3. Baron, M., \& Kenny, A. (1986). The moderator-mediator variable distinction in social psychological research: conceptual, strategic, and statistical considerations. Journal of Personality and Social Psychology, 51(6), 1173-1182. http://dx.doi.org/10.1037/00223514.51.6.1173

4. Barth, M., Beaver, W., \& Landsman, W. (2001). The relevance of the value relevance literature for financial accounting standard setting: another view. Journal of Accounting and Economics, 31(1-3), 77-104. https://doi.org/10.1016/S01654101(01)00019-2
5. Beaver, W. (1998). Financial Reporting: An Accounting Revolution. NJ: Prentice-Hall, Englewood Cliffs.

6. Beneish, M. D., Billings, M., \& Hodder, L. (2008). Internal control weaknesses and information uncertainty. The Accounting Review, 83(3), 665-703. https://doi. org/10.2308/accr.2008.83.3.665

7. Chan, K., Farrell, B., \& Lee, P. (2008). Earnings management of firm reporting material internal control weaknesses under section 404 of the Sarbanes-Oxley Act. A Journal of Practice \& Theory, 27(2), 161-179. https://doi.org/10.2308/ aud.2008.27.2.161

8. Choe, H., Kho, B. C., \& Stultz, R. M. (1999). Do foreign investors destabilize stock markets? The Korean experience in 1997. Journal of Financial Economics, 54(2), 228-264. https://doi.org/10.1016/S0304405X(99)00037-9

9. Choi, J., Choi, S., Hogan, C., \& Lee, J. (2013). The effect of human resource investment in internal control on the disclosure of internal weaknesses. Auditing: A Journal of Practice and Theory,
32(4), 169-199. https://doi.

org/10.2308/ajpt-50514

10. Collins, D., \& Kothari, S. P. (1989). An analysis of the intertemporal and cross-sectional determinants of the earnings response coefficient. Journal of Accounting and Economics, 11(2-3), 143-181. https://doi.org/10.1016/01654101(89)90004-9

11. COSO (The Committee of Sponsoring Organizations). (2013). Internal Control-Integrated Framework. Retrieved from http:// www.coso.org

12. Dechow, P., \& Dichev, I. (2002). The quality of accruals and earnings: The role of accrual estimation errors. The Accounting Review, 77(s-1), 35-59. https://doi. org/10.2308/accr.2002.77.s-1.35

13. Deloitte Development LLC. (2013). COSO 2013 Framework on Internal Control Prepare for the changes. Retrieved from https:// chapters.theiia.org/Orange $\% 20$ County/IIA\%20OC\%20Presentation\%20Downloads/COSO\%20 Training_Deloitte.pdf

14. Dhaliwal, D. S., Lee, K. J., \& Fargher, N. L. (1991). The association between unexpected 
earnings and abnormal security returns in the presence of financial leverage. Contemporary Accounting Research, 8(1), 20-41. https://doi. org/10.1111/j.1911-3846.1991. tb00832.x

15. Doyle, J., Ge, W., \& McVay, S. (2007). Accruals quality and internal control over financial reporting. The Accounting Review, 82(5), 1141-1170. https://doi. org/10.2308/accr.2007.82.5.1141

16. Fama, E., \& French, K. (1995). Size and book-to-market factors in earnings and returns. Journal of Finance, 50(1), 131-155. https:// doi.org/10.1111/j.1540-6261.1995. tb05169.x

17. Fama, E., \& French, K. (2006). Profitability, investment and average returns. Journal of Financial Economics, 82(3), 491518. https://doi.org/10.1016/j. jfineco.2005.09.009

18. Fargher, N., \& Gramling, A. (2005). Toward improved internal controls: early remediation actions disclosed. The CPA Journal, 75(6), 26-29. Retrieved from http://archives.cpajournal.com/2005/605/ essentials/p26.htm

19. Francis, J., \& Ke, B. (2006). Disclosure of fees paid to auditors and the market valuation of earnings surprises. Review of Accounting Studies, 11(4), 495-523. https://doi.org/10.1007/s11142006-9014-Z

20. Francis, J., \& Schipper, K. (1999). Have financial statement lost their relevance? Journal of Accounting Research, 37(2), 319-352. https:// doi.org/10.2307/2491412
21. Francis, J., LaFond, R., Olsson, P., \& Schipper, K. (2004). Costs of equity and earnings attributes. The Accounting Review, 79(4), 967-1010. https://doi.org/10.2308/ accr.2004.79.4.967

22. Frankel, R., Johnson, M., \& Nelson, K. (2002). The relation between auditors' fee for nonaudit services and earnings management. The Accounting Review, 77, 71-105. Retrieved from http://www.jstor.org/stable/3203326

23. Ge, W., \& McVay, S. (2005). The disclosure if material weaknesses in internal control after the Sarbanes-Oxley Act. Accounting Horizons, 19(3), 137158. https://doi.org/10.2308/ acch.2005.19.3.137

24. Hammersley, J. S., Myers, L., \& Shakespeare C. (2008). Market reactions to the disclosure of internal control weaknesses and to the characteristics of those weaknesses under section 302 of the Sarbanes Oxley Act of 2002. Review of Accounting Studies, 13(1), 141-165. https://doi. org/10.1007/s11142-007-9046-Z

25. Lee, J. (2015). Internal control weakness and investment efficiency: Evidence from Korea. Korean Accounting Review, 40(2), 109-149. http://www.kaa-edu. or.kr/html/sub03_03.asp

26. Lemmon, M. L., \& Lins, K. V. (2003). Ownership structure, corporate governance, and firm value: Evidence from the East Asian Financial Crisis. The Journal of Finance, 58(4), 1445-1468. https://doi.org/10.1111/15406261.00573
27. Nissim, D., \& Penman, S. (2001). Ratio Analysis and Equity Valuation: From Research to Practice. Review of Accounting Studies, 6(1), 109-154. https://doi. org/10.1023/A:1011338221623

28. Ohlson, J. (1995). Earnings, book values and dividends in security valuation. Contemporary Accounting Research, 11(2), 661-687. https://doi. org/10.1111/j.1911-3846.1995. tb00461.x

29. Ou, J., \& Penman, S. (1989). Financial statement analysis and the prediction of stock returns. Journal of Accounting and Economics, 11(4), 295-329. https://doi.org/10.1016/01654101(89)90017-7

30. PCAOB (Public Company Accounting Oversight Board). (2008). Audit considerations in the current economic environment (Staff Audit Practice Alert No. 3). Washington. D. C. Retrieved from https://pcaobus.org/ Standards/QandA/12-05-2008 APA_3.pdf

31. Rattiner, J. H. (2008). Financial Planning Answer Book. Chicago: $\mathrm{CCH}$.

32. Reilly, F. K., \& Brown, K. C. (2011). Investment Analysis and Portfolio Management. Mason, $\mathrm{OH}$ : Cengage Learning.

33. Shin, I., Lee, H., Lee, H., \& Son, M. (2016). How does human resource investment in internal control affect audit reporting lag? Asia-Pacific Journal of Accounting and Economics, 24(1-2), 195-215. https://doi.org/10.1080/16081625 2015.1135751 